\title{
Glauber Rocha no caminho da televisão
}

Paulo Roberto de Azevedo Maia"

Resumo: Esse artigo tem como proposta analisar a trajetória intelectual de Glauber Rocha, partindo de suas experiências políticas e culturais ao longo dos anos 1970 até se tornar apresentador de televisão. Em sua produção cinematográfica feita no exterior é possível perceber uma aproximação com a linguagem televisiva, numa espécie de preparação inconsciente para atividade que viria desenvolver. Além dos filmes, foi motivo de análise a produção intelectual expressa em livros, jornais e revistas. Em 1979, o cineasta baiano teve uma experiência de apresentador no programa Abertura veiculado pela Rede Tupi de televisão. Apesar de ficar apenas 9 meses no ar, sua participação foi intensa, configurando um dos momentos mais significativos da televisão brasileira da década de 70.

Palavras-chave: Televisão. Abertura. Glauber. Cinema.

\section{Introdução}

Provocativo, inconsequente, popular, autoritário, genial e profeta. Esses são alguns termos usados para definir o cineasta Glauber Rocha. Seu cinema representa inovação e coragem ao desenvolver mudanças linguísticas e propostas estéticas que bem definiram o que era a estética da fome do cinema novo e ganhou dimensão internacional, sendo conhecido em grande parte do mundo. Glauber usou o cinema para revelar a sua leitura de Brasil, discutindo problemas sociais, vícios políticos e características

\footnotetext{
"Professor na Universidade Federal da Paraíba (UFPB). Doutorado em História pela Universidade Federal Fluminense (UFF).

E-mail: paulomaia@cchla.ufpb.br, https://orcid.org/0000-0001-8330-6491
}

Anos 90, Porto Alegre, v. 25, n. 48, p. 327-349, dez. 2018 
próprias da cultura brasileira. Mas, não se limitou a fazer essa leitura apenas com sua câmera. A máquina de escrever e, às vezes, sua caneta lhe foram úteis para revelar seu pensamento através de livros e artigos escritos na grande imprensa. O seu último trabalho demonstrou o interesse de expandir o seu público e vivenciar uma nova experiência estética. A televisão, considerada por Glauber o "cinema popular por excelência", guardou, nas imagens do programa Abertura, um pouco de todos os adjetivos atribuídos a ele e revelou a continuidade de seu pensamento em um veículo novo, mas eficaz para discutir questões variadas e, em particular, a abertura política. Reconhecendo a importância da participação do cineasta baiano no programa por sua irreverência e destaque na imprensa da época, mas principalmente por se tratar do grande modelo de intelectual herdeiro da tradição contestatória romântica revolucionária dos anos 1960 é que tenho como proposta, nesse artigo, analisar a trajetória intelectual de Glauber Rocha, partindo de suas influências políticas, culturais e sociais ao longo dos anos 1970 até se tornar apresentador de televisão. Em sua produção cinematográfica feita no exterior é possível perceber uma aproximação com a linguagem televisiva, numa espécie de preparação para atividade que viria desenvolver.

O programa Abertura surgiu pela iniciativa do produtor Fernando Barbosa Lima e tinha como proposta discutir o processo de abertura política no exato momento em que este se intensificava com o início do governo de João Baptista Figueiredo. Ia ao ar todos os domingos às 22:30 horas pela Rede Tupi e contava com a participação de artistas, intelectuais e políticos de variadas tendências. Fausto Wolf, Villas Boas Corrêa, Roberto D’Ávila, Tarcísio Holanda, Norma Bengel e Ziraldo são alguns dos nomes aos quais se juntou Glauber Rocha para discutir a cultura brasileira, o imperialismo americano, a censura, a anistia, entre outros assuntos.

A participação de Glauber Rocha no Abertura foi pequena comparada à duração do programa que foi ao ar de fevereiro de 1979 até maio de 1980. Glauber participou com seu quadro de fevereiro a outubro de 1979, mas, apesar do curto período, teve uma participação intensa, constituindo-se num dos momentos mais importantes da televisão brasileira do final da década de 1970. 


\section{Glauber descobre a televisão}

A experiência do cinema era, na visão de Glauber Rocha, sacralizada pelos cineastas que não admitiam um veículo considerado destituído de atributos estéticos como significativo agente de transformação. ${ }^{1}$

Mas, para o cineasta baiano, a televisão não era vista apenas como um instrumento de alienação a serviço da burguesia e do imperialismo. A diferença entre televisão e cinema era identificada na forma de exibição, pois a produção era a mesma, independente do veículo de transmissão (ROCHA, 2004, p. 187). Não se leva em consideração a polêmica dessa afirmação, já que existem diferenças de linguagem que iremos discutir adiante. A aproximação entre público e cinema foi uma preocupação para Glauber que não via mais sentido em manter um ritual cinematográfico baseado na produção de filmes e divulgação através de festivais. Rompendo o preconceito de cineastas em relação à televisão, o cineasta começou a refletir sobre a importância de levar o filme ao grande público e a televisão poderia, com sua competência de veículo de massas, ter o papel de divulgador de experiências cinematográficas capazes de interferir na realidade social:

Há que se acabar com o ritual cinematográfico. $\mathrm{O}$ cinema tem que existir, hoje, além da informação, da polêmica e da discussão [...]. Temos que meter isso na cabeça: a importância da TV. Mas o cineasta da América Latina ainda quer ir a festivais, aparecer nos Cahiers, ideias subdesenvolvidas próprias de literatos do século XIX. O assunto é outro: é aproveitar a tecnologia possível para conseguir a maior comunicação possível (ROCHA, 2004, p. 188).

A declaração de Glauber, feita na época do lançamento do Dragão da Maldade contra o Santo Guerreiro, em 1969, era o sinal do interesse de uma aproximação com a televisão desejada pelo diretor que teve seus filmes veiculados pela TV europeia (ROCHA, 2004, p. 63), mas uma presença efetiva só iria se concretizar em 1979 com o programa Abertura. Sua participação na televisão foi 
a última possibilidade de Glauber divulgar seu pensamento, depois do programa não houve nenhuma produção até sua morte em 22 de agosto de 1981. Trata-se de um esforço de levar aos telespectadores conceitos, críticas e devaneios já conhecidos do público letrado que acompanhou sua produção cinematográfica e bibliográfica. Seu trabalho na televisão não pode ser considerado uma negação do cinema, afinal, Glauber afirmou: "Cinema, para mim, é filme, não importa se é ótico ou em tape, ou se passa no cinema ou na sala da nossa casa. O que interessa não é a técnica, mas o homem que está por trás da câmera” (CAMBARÁ, 1979, p. 62).

\section{Do cinema à televisão}

A atividade cinematográfica de Glauber foi intensa durante os anos de 1960. Barravento (1962), Deus e o Diabo na Terra do Sol (1963), Terra em Transe (1967) e O Dragão da Maldade contra o Santo Guerreiro (1968) demonstram uma produção apurada focada nos problemas sociais, mas, ao ir para o exterior, em 1970, começou uma trajetória que o levaria a uma discussão mais minuciosa sobre a realidade brasileira e latino-americana, abrindo espaço para pensar o subdesenvolvimento de forma mais ampla, discutindo o colonialismo e propostas revolucionárias na convergência da realidade do subdesenvolvimento, temas bastante comuns na época. Em relação à discussão sobre o problema do colonizado, que fez parte das reflexões do cinema novo, não apenas através de sua cinematografia, mas também pela proposta teórica que concebia a América Latina como presa à dominação colonial diferenciada do passado, apesar da permanência dos antigos colonizadores, temse que o perigo vinha das artimanhas dos países interessados em manter um poder possivelmente imperialista sobre a América o que descaracterizaria a possibilidade de liberdade de fato num período de curto prazo. Segundo Glauber:

A América Latina permanece colônia e o que diferencia o colonialismo de ontem do atual é apenas a forma mais 
aprimorada do colonizador: e além dos colonizadores de fato, as formas sutis daqueles que também sobre nós armam futuros botes. O problema internacional da AL é ainda um caso de mudança de colonizadores, sendo que uma libertação possível estará ainda por muito tempo em função de uma nova dependência (ROCHA, 2012).

A preocupação com o imperialismo e o colonialismo de Glauber atravessou fronteiras, chegando a Europa e África. Conhecido internacionalmente por seus filmes e artigos escritos em publicações europeias e norte-americanas, o cineasta conseguiu convites para filmar no exterior, garantindo orçamentos capazes de viabilizar projetos com ampla liberdade de criação. Orientado pelo espírito de crítica anticolonialista, realizou em 1970, no Congo, uma produção ítalo-francesa intitulada $O$ Leão de sete cabeças, cujo título original era Der Leone have sept cabeças. O título, com sua mistura linguística, fazia uma alusão aos países colonizadores como França, Alemanha, Inglaterra, Itália e Portugal. O filme faz dos personagens arquétipos da sociedade mundial, bem no estilo de Terra em Transe. Assim, cada personagem tem uma representação como: o imperialismo, a Igreja, o revolucionário, o mercenário e a burguesia local. Tratava da colonização no âmbito de uma dominação europeia e a relação de repressão exercida contra o homem africano, mas de uma forma metafórica retratava a complexidade da dominação pelo olhar do homem do terceiro mundo. Glauber definiu seu filme como:

É uma história geral do colonialismo euro-americano na África, uma epopeia africana, preocupada em pensar do ponto de vista do homem do terceiro mundo, por oposição dos filmes comerciais que tratam de safáris, ao tipo de concepção dos brancos em relação àquele continente. É uma teoria sobre a possibilidade de um cinema político. Escolhi a África porque me parece um continente com problemas semelhantes aos do Brasil (JORNAL DA TARDE, 1970). 
Ainda em 1970, produziu na Espanha, com grande parte da equipe formada por espanhóis, a obra cinematográfica Cabeças Cortadas. Nesse filme, Glauber continua sua incursão pelo universo da repressão e das ditaduras e segundo ele:

Cabeças Cortadas é um filme contra as ditaduras, é o funeral das ditaduras. Trato de um personagem que seria o encontro apocalíptico de Perón com Franco, nas ruínas da civilização latino-americana. Filmei nas pedras de Cadaquês, onde Buñuel filmou L'âge d'or. A Espanha é a Bahia da Europa. Cabeças Cortadas desmonta todos os esquemas dramáticos do teatro e do cinema. O cinema do futuro será som, luz, delírio, aquela linha interrompida desde L’âge d'or (ROCHA, 1979).

O funeral das ditaduras propagada no filme refletia o paradoxo da América Latina envolvida em regimes ditatoriais, como no caso do Brasil, uma junta militar dominando a Argentina em meio a movimentos de contestação do regime e a possibilidade de socialismo do governo Salvador Allende no Chile. Era um libelo otimista do fim das ditaduras. "O filme se referenda a Franco ou a Perón numa base muito relativa porque, na verdade, o filme fala de todos os ditadores, de todos os patriarcas decadentes" (ROCHA, 2006, p. 12).

Esses filmes marcaram o início de uma nova fase do cinema de Glauber que vinha sendo propagada em ensaios em revistas, correspondências, debates e em festivais de cinema. Era a proposta de um "cinema Tricontinental”, "um programa estético e político que deveria expressar a originalidade histórica do Terceiro Mundo e seria uma força revolucionária capaz de transformar a cultura do homem colonizado, rompendo com as visões de mundo difundidas pelo cinema norte-americano" (CARDOSO, 2008, p. 4). Esse cinema múltiplo geograficamente seria a forma de reafirmar o cinema do subdesenvolvimento na relação entre dominadores e dominados ou nas palavras de Glauber poder realizar um cinema do "terceiro mundo". A escolha do continente africano para realizar $O$ Leão de sete cabeças seria uma decisão de caráter político rumo 
à composição do cinema Tricontinental. Para Glauber, a África seria o caso exemplar do contexto explosivo do terceiro mundo, podendo fazer um filme que poderia ser chamado de filme do terceiro mundo ou mesmo de filme Tricontinental.

Cabeças cortadas, ao contrário do que aconteceu em Cannes, em 1969, com O Dragão da Maldade contra o Santo Guerreiro que ganhou o prêmio de melhor diretor, consagrando Glauber como um dos mais importantes cineastas do mundo (CARDOSO, 2008, p. 3), foi duramente recebido pela crítica internacional que o considerou demasiadamente simbólico e distante da realidade. Apesar dos comentários desfavoráveis, sua presença enquanto cineasta engajado política e esteticamente garantiu a decisão de partir, em 1971, para um exílio voluntário, já que as condições políticas se mostravam desfavoráveis, limitando sua liberdade de criação. Em entrevista concedida a Miguel Pereira, Glauber revelou a impossibilidade de continuar fazendo cinema no Brasil com a rigidez de um regime que não permitia levar adiante o olhar crítico e combativo. Não existiam condições ideais no Brasil para o cinema que fazia e com "[...] o AI-5 e a dureza da censura, eu vi que não tinha muito espaço criativo, perderia muito tempo aqui e envelheceria no Brasil esperando as aberturas que duraram 15 anos para chegar" (ROCHA, 1979).

Reconhecido internacionalmente como um grande cineasta, Glauber Rocha manteve contato com autoridades, artistas e exilados brasileiros na Europa e na América Latina. Assim, depois de ir para Nova York, o cineasta foi para Cuba onde viveu como convidado do governo, trabalhando afinado com a temática libertária do cinema latino-americano proposto por Cuba através do ICAIC, Instituto Cubano del Arte e Indústria Cinematográficos, cuja missão do cinema ia ao encontro das perspectivas do Cinema Novo.

Glauber passou a atuar no ICAIC e manteve forte amizade com Alfredo Guevara, diretor do instituto e grande defensor do cinema intervencionista nas questões sociais. Aliás, essa amizade já pode ser percebida mesmo antes de sua chegada a Cuba. Ao longo da década de 1960 mantiveram uma correspondência regular. A primeira carta de Glauber foi escrita em fins de 1960 quando, entusiasmado com as possibilidades de mudanças em Cuba, saudou 
a revolução e sugeriu um intercâmbio cultural de filmes entre os dois países (CARDOSO, 2008, p. 2). Através das cartas, Glauber mantinha Alfredo Guevara informado sobre a produção cinematográfica brasileira, revelava suas posições sobre a conjuntura política nacional, suas impressões sobre o cinema em geral e os festivais estrangeiros de cinema. Explicitava seus ideais de um cinema de denúncia, mas ressaltava a necessidade de ficar atento aos diretores que denunciavam a miséria do povo através de estratégias linguísticas típicas da cinematografia tradicional do tipo Hollywoodiana. Para ele, o filme revolucionário era legítimo por não representar uma estética imperialista, daí decorria a responsabilidade dos cineastas com a qualidade das obras, pois "[...] os filmes revolucionários têm de ser melhores que os filmes reacionários em todos os níveis” (ROCHA, 1997, p. 411). Essa convicção partia de um embasamento teórico de fundo marxista que procurava entender o homem, não apenas dentro de parâmetros materiais, mas dentro do universo da arte, por isso "quando Marx denunciou a escravidão econômica do homem, estava pregando uma sociedade onde o homem não existisse em função da economia. Por isso os artistas são tão necessários à sociedade quanto os engenheiros” (ROCHA, 1997, p. 411).

As cartas de Glauber deixavam o cubano consciente da relação entre os intelectuais filiados ao Partido Comunista e o Cinema Novo que era pautada pelo dilema do engajamento político defendido pela intelectualidade de esquerda e o experimentalismo dos diretores. Alfredo Guevara, por outro lado, enviou filmes cubanos, revistas do ICAIC e solicitava mais informações sobre os diretores brasileiros que eram considerados interessantes para serem divulgados em Cuba (ROCHA, 1997, p. 411).

O trabalho de Glauber no ICAIC levou, junto com o cineasta Marcos Medeiros, a produção do documentário História do Brasil, iniciado em Cuba em 1972 e finalizado em Roma em 1974. Era uma tentativa de fazer uma história total do nosso país. Conta a história do Brasil dos primórdios da expansão marítima, a chegada dos portugueses, colonização, império, período republicano, passando por todos os episódios relevantes até o golpe de 1964, a radicalização com o AI-5, o sequestro do embaixador americano Charles Burke Elbrick, a morte de Carlos Lamarca, o período do 
presidente Garrastazu Médici, finalizando com a posse do general Ernesto Geisel. O documentário foi desenvolvido com a utilização de fontes variadas como filmes de ficção brasileiros e cubanos, cinejornais, telejornais, fotojornalismo, pinturas e outros materiais visuais (CARDOSO, 2008, p. 9). A narrativa visualmente rica era acompanhada do som caracterizado pela voz over e com músicas populares e eruditas. $\mathrm{O}$ filme era um esforço de fazer uma análise mais abrangente da história do Brasil em uma perspectiva "totalizadora" a partir do estudo da historiografia nacional e internacional sobre o tema, pois, segundo o cineasta, ele teria passado um ano na pesquisa bibliográfica e acrescenta:

De 1500 a 1973 dei atenção e valor a todos os seus principais componentes: o econômico, o político e o social. $\mathrm{O}$ roteiro foi feito com bibliografia brasileira especializada e com aquela internacional que pude consultar. Vivi um ano pesquisando. Foi quando me dei conta de que nunca se fez, e por isso não existe, uma versão integrada de todos os aspectos da História do Brasil. Tudo que encontrei foram versões setorizadas nos livros de Euclides da Cunha, José Veríssimo, Sérgio Buarque de Holanda, Celso Furtado, Darcy Ribeiro, Gilberto Freyre, Fernando Henrique Cardoso e em muitos outros (NETTO, 1973).

As intenções de Glauber com o documentário, ao propor uma história totalizante, seria a de superar as visões parciais sugeridas pela literatura estudada por ele onde constata a insuficiência da historiografia. Esse olhar de cronista, crítico da produção acadêmica foi no programa Abertura uma de suas características mais marcantes.

Ao longo de toda a década de 1970, o pensamento de Glauber Rocha foi divulgado através de diversos artigos escritos na grande imprensa, principalmente o Jornal do Brasil e Folha de São Paulo. Mas, o pensamento do cineasta não ficou consignado ao papel. A prática de conceder entrevistas era regular e, de certa forma, seus ensaios eram uma sistematização do pensamento divulgado nas entrevistas. Continham o peso de uma mente dinâmica que muitas vezes em função do radicalismo gerava polêmica. 
Observando as narrativas de Glauber, tudo indica que o pensamento fora dos padrões da moderna sociedade de consumo era o único que poderia ser considerado independente e, portanto, válido para uma autêntica representação da realidade. Sua postura crítica e irreverente era expressão de discursos que não poupavam ninguém. (6) Era uma metralhadora de pensamentos a criticar artistas, políticos e o governo, e, ao mesmo tempo, tecendo elogios aos presidentes militares e ao esforço de levar o Brasil para a abertura política.

A linguagem do cinema mantém distância da televisão em vários aspectos e, apesar de Glauber Rocha não valorizar as diferenças, sua forma de filmar adquiriu contornos de linguagem televisiva, em particular nas produções dos filmes Câncer, Claro e Di Glauber.

Câncer foi filmado em $1968 \mathrm{em}$ apenas quatro dias e finalizado em 1972. A demora se justifica pelo desinteresse do diretor que considerava o filme uma experiência prazerosa de se fazer, mas que não teria outra função. Seu olhar sobre sua própria obra esclarece a questão:

Câncer é um filme particular, não vou enviá-lo a festivais, nem vou exibi-lo nos cinemas. Ou talvez o exiba, mas ainda não o terminei, falta fazer a montagem. No momento não estou interessado em fazê-lo porque meu prazer foi só filmá-lo e suponho que talvez o que esteja lá não tenha importância (ROCHA apud MELO, 2012).

Embora o próprio Glauber não tenha visto grande importância no seu filme naquele momento, ele se diferencia dos demais do cinema novo, com propostas estéticas mais próximas do cinema underground. $\mathrm{O}$ marginal tomando conta e criando novas possibilidades que acabariam por se tornar o início de uma nova prática de linguagem cuja montagem foi o grande diferencial. "Câncer marca um dos primeiros movimentos em direção a uma nova concepção de montagem que terá reflexos decisivos até mesmo nos programas que Glauber irá realizar na TV Tupi, em Abertura (1979)" (ROCHA apud MELO, 2012).

A inovação, em termos de montagem, surgiu em uma obra sem preocupações políticas explícitas, embora, como diz Lukács, 
toda obra de arte bem-sucedida tem algo a dizer sobre a sociedade de seu tempo ou "[...] toda obra de arte toma partido diante do mundo" (LUKACS, 2009. p. 208). Câncer retrata três personagens interpretados por Antônio Pitanga, Hugo Carvana e Odete Lara, mas não se configura em uma história, revela os personagens em diversas ações de violência. Glauber fez um filme para trabalhar as possibilidades do cinema e não para simplesmente contar uma história. Queria mostrar que "o caminho do cinema são todos os caminhos" (ROCHA, 2004, p. 180). Contrariando os discursos de que o filme em cores e o $35 \mathrm{~mm}$ seriam a única possibilidade de fazer cinema, Câncer revela a grande gama de possibilidades da atividade cinematográfica. É um combate aos preconceitos.

Em vez de fazer uma superprodução em cores fiz um filme em $16 \mathrm{~mm}$, com equipamento reduzido, para mostrar que alguém pode fazer tudo, que não existem preconceitos. Minha guerra é contra isto: a intolerância, os preconceitos, a demagogia (ROCHA, 2004, p. 180).

O filme inverteu o sentido da linguagem cinematográfica tradicional que procura encantar o espectador pela ilusão, o que implica em não deixar explícitas as formas de produção, ao sair do ocultamento do procedimento técnico e revelar o processo de realização:

[...] a partir de uma desnaturalização da narrativa e da reflexão sobre o próprio filme na introdução falada, em off, por Glauber. Pode-se propor que, em Câncer, há uma ruptura com os modos de visualidade instituídos e um questionamento das possibilidades de filmar (LIMA, 2011, p. 5).

O filme Claro, de 1975, é uma das experiências na qual o espírito do documentário misturado com a ficção procuram levar ao público reflexões sobre a dinâmica do mundo com seus conflitos. Com uma única personagem, a atriz francesa Juliet Berto, esposa do cineasta na época, fica no centro de Roma divagando pelos mais 
diversos assuntos. Representa a figura do intelectual e o desejo de fazer um filme manifesto. $\mathrm{O}$ cenário de Roma serve para fazer o contraponto entre a capital do antigo Império romano e as forças imperialistas do momento, numa referência aos Estados Unidos. O filme se passa, em grande parte, na área do sítio histórico de Roma, mas também em outros pontos históricos da cidade como a praça de São Pedro, lugar propício para Glauber poder rodar com sua câmera e capturar imagens de pessoas comuns na sua diversidade, imigrantes, turistas, cineastas, proletários, policiais, comunistas, burgueses, africanos, católicos e sindicalistas aparecem como personagens reais representando a tomada da Europa pelo terceiro mundo (ARAÚJO, 2012). A referência aos acontecimentos da época, como a vitória do Vietnã na guerra contra os Estado Unidos, aparece, de forma sutil, com imagens de revistas internacionais mostrando Ho Chi Minh. O líder socialista surgia como expressão da vitória da periferia sobre o centro, reafirmando a lógica inserida no filme.

Um destaque que torna importante a referência desse filme para compreendermos o programa Abertura é o fato de ter sido o primeiro feito por Glauber Rocha no qual ele vai para o meio do público e faz entrevistas. A primeira experiência nesse sentido foi a participação no filme Armas e o Povo de 1974, produção de vários cineastas que retrata a revolução dos cravos em Lisboa e onde Glauber foi para os bairros pobres da cidade para revelar, através de entrevistas, o pensamento do sujeito comum sobre a volta da democracia a Portugal. A mesma prática foi feita em Claro e era recorrente no programa Abertura.

$\mathrm{O}$ último filme produzido no período anterior à experiência na televisão foi Di Glauber, em 1977. A polêmica causada com essa produção, só não foi maior do que a mudança linguística no estilo do cineasta aplicada no filme. A família de Di Cavalcanti entrou com um pedido na justiça para que o filme fosse proibido de ser exibido, o que foi acatado pela justiça. Isso não impediu que Glauber Rocha inscrevesse o curta-metragem no Festival de Cannes e ganhasse o prêmio da crítica especializada. Nessa obra, ele propõe um espaço para o cinema de intervenção, manifestando um interesse documental, de apreender a realidade no exato momento de seus acontecimentos. Filma o velório do pintor Di Cavalcanti, 
a movimentação das pessoas, o corpo do pintor no centro do salão, a tristeza da família e amigos, sempre com sua voz off ao fundo. Faz um cinema que se aproxima da linguagem da televisão, principalmente pelo tom de reportagem que às vezes sobressai. Em muitos momentos, apesar de manter a voz off, o curta-metragem foge do padrão clássico e os atores Joel Barcellos, Marina Montini e Antônio Pitanga entram em cena para compor a homenagem ao pintor. A narrativa de Glauber varia, resgatando a poesia Balada de Di Cavalcanti de Vinicius de Moraes, enquanto o ator Antônio Pitanga, em uma filmagem feita na área de exposição do Museu de Arte Moderna do Rio de Janeiro no qual aconteceu o velório, dança, festeja numa alusão à figura do pintor considerado boêmio e festeiro. É uma representação feita para homenagear o amigo. Em outro momento, a narração adquire ares de depoimento quando narra como o diretor conheceu Di Cavalcanti em 1958, ainda como repórter do jornal Diário de Notícias da Bahia, foi incumbido de entrevistar Roberto Rossellini que estava visitando o Brasil na companhia do pintor. Narra outros encontros em anos posteriores, 1964, depois no início dos anos 1970, o encontro em Paris e cita telefonemas entre os dois. Na última parte do filme faz a leitura de um texto de Frederico Morais analisando a obra de Di Cavalcanti. $\mathrm{O}$ que mais chama a atenção é a forma como utiliza um recurso discursivo que se tornará o marco de seu quadro no programa Abertura, a metalinguagem. "Em Di Glauber, a autorreflexão leva o espectador a pensar sobre o processo de filmagem, a partir do momento em que Glauber 'revive', por meio da leitura da matéria de jornal sobre sua própria filmagem, os momentos de captação de imagem" (MATTOS, 2004, p. 164). Essa é a primeira parte da narração do filme onde apresenta várias manchetes publicadas nos dias posteriores ao velório sobre a gravação do documentário. A intervenção de Glauber no curta acaba transformando ele próprio em mais um personagem.

Observando a obra de Glauber Rocha, O Leão de sete cabeças com sua temática anticolonialista e anti-imperialista; Cabeças Cortadas como libelo contra as ditaduras; Câncer, uma incursão no universo underground; Claro e a aproximação do cineasta com o povo, surgindo o diretor entrevistador e Di-Glauber, a experiência 
do imediato, do improvisado se misturando ao cinema documentário. O trabalho realizado no programa Abertura da Rede Tupi teve nessa trajetória o alicerce teórico e técnico do ponto de vista da constituição da linguagem e as preocupações que sempre estiveram presentes com o cineasta já estavam em suas obras e o acompanharam para a televisão.

\section{Alô, Alô, povo do sertão, carne, arroz e feijão}

As reflexões sobre o Brasil feitas na imprensa já não mais davam conta de passar ao grande público o que Glauber desejava. Era necessário unir o discurso às imagens, o que só a televisão poderia proporcionar com agilidade e cujos efeitos poderiam ser constatados já na manhã seguinte.

A participação de Glauber Rocha no Abertura teve início com o convite de Carlos Alberto Lofer, amigo pessoal do cineasta e um dos diretores do programa junto com Carlos Alberto Vizeu (VIZEU, 2011). Outros nomes já haviam sido cogitados para fazer o quadro de crítica cinematográfica que, aliás, acabou se tornando, ao contrário do esperado, um momento de discussões ecléticas, indo da crítica política, econômica e social até a discussão do cinema, da cultura e da fala desordenada do apresentador e de seus convidados. O quadro era simples, não existiam esquemas fixos e a cada semana o telespectador assistia uma novidade que podia ser, às vezes, um monólogo para expor o pensamento de Glauber e em outros entrevistas com as mais variadas personalidades. Famosos como o cantor Caetano Veloso, o produtor musical Nelson Mota, o produtor de cinema Luís Carlos Barreto, o filósofo Luís Carlos Maciel, o político baiano Antônio Carlos Magalhães, o psicanalista Eduardo Mascarenhas, e anônimos como o funcionário do jogo do bicho, Brizola, além, é claro, de seu fiel companheiro, membro da equipe técnica e responsável pelos cabos, Severino.

A presença de Glauber na televisão gerou reações na grande imprensa. Cineastas na telinha já eram comuns no trabalho por trás das câmeras, mas não como apresentador. A jornalista Isa Cambará, da Folha de São Paulo, acompanhou a gravação de um dos 
programas e avaliou o quadro com comentários que identificam a singularidade da participação do cineasta. A jornalista considerou a frase inicial do quadro de Glauber no Abertura, "Alô, Alô, povo do Sertão, carne, arroz e feijão", digna de Chacrinha. ${ }^{2}$ A comparação com o "Alô, Alô Teresinha" vai muito além da frase. Para ela, a participação de Glauber no programa Abertura é um dos momentos mais provocativos e polêmicos da televisão brasileira daquele momento. $\mathrm{O}$ estilo anárquico de Chacrinha era o tom de Glauber. Porém, a comparação não ficava restrita ao comportamento no ar, mas também pelo domínio de cena. Para as pessoas ligadas a televisão, Abelardo Barbosa era uma grande figura do meio por entender a composição de ângulos durante as filmagens. O domínio da câmera com movimentos próprios de quem tem intimidade com máquina fílmica fizeram valer a comparação com o "velho guerreiro", mas ao contrário de manter apenas o visual e frases desconexas como o apresentador de auditório, sua arma mais poderosa, a palavra, era usada para expressar ideias independentes do endereço de entrega. A jornalista afirmou que Glauber estava se firmando como o novo mito de comunicação da televisão brasileira e acrescentou:

Em quatro meses de atividade no programa "Abertura", da Tupi, Glauber conseguiu causar mais polêmicas do que todos seus filmes juntos. Há a quem o chame de picareta, de explorador de gente simples (que são, quase sempre, seus entrevistados) e, como não poderia deixar de ser, de louco varrido (CAMBARÁ. 1979, p. 62).

A metodologia da apresentação do quadro chamava a atenção pelo improviso dentro do espírito anárquico habitual de Glauber que era responsável pela sua própria direção e considerava desnecessário qualquer roteiro, afirmando que "diretor que trabalha com roteiro é mestre de cerimônia” (CAMBARÁ. 1979, p. 62). A liberdade de criação dava-se de forma completa, sem pauta a ser seguida "o assunto é escolhido na hora, no meio da rua, e qualquer repórter que esteja ali a serviço pode passar, de uma hora para outra, de entrevistador a entrevistado” (CAMBARÁ. 1979, p. 62). Essa prática negava padrões já sacralizados do jornalismo brasileiro, no qual havia uma definição 
clara dos papéis de entrevistador e entrevistado, o que levou a uma indagação sobre a natureza do trabalho de Glauber, se isso poderia ser considerado jornalismo, o que pelo distanciamento de modelos clássicos podia ser negado, mas o cineasta, frente a esta questão afirmava: "Não é jornalismo, nem cinema, é a vida" (CAMBARÁ. 1979, p. 62). Afirmações como essa garantiam críticas que atribuíam ao quadro o título de sensacionalista.

Contrariando o pensamento do cineasta, Carlos Alberto Vizeu avalia a participação de Glauber como expressão de atividade cinematográfica, não como uma produção de filme qualquer, mas como uma produção cinematográfica para o Abertura, voltada para o desenvolvimento das questões caras ao programa que trazia o tema da redemocratização. "Ele fazia na verdade um cinema para o Abertura. Ele fazia um filme para o Abertura. E esse filme podia ser uma entrevista. Podia ser ele parar um caminhão no meio da rua e fazer uma entrevista com o motorista" (VIZEU, 2011).

Com uma produção cinematográfica e ensaística tão instigante e polêmica, não teve como Glauber fugir das críticas que lhe acompanharam a vida inteira. $\mathrm{Na}$ televisão não foi diferente e teve quem visse no seu quadro um caráter nostálgico que remetia aos primeiros filmes do cineasta onde o tom provocativo era inequívoco. O jornalista Nonato Cruz definiu a participação de Glauber no Abertura como:

o repórter conturbado, agressivo, como seu cinema na primeira fase, é o anticonvencional por excelência. A rigor, é um personagem que precisa ser entendido: não é o sensacionalismo que em alguns instantes pode aparentar, é o novo, o agressivo meio bombástico, em toda sua plenitude (CRUZ apud MOTTA, 2001).

A novidade de Glauber na televisão não era tão grande para os que conheciam seu trabalho, seus filmes e artigos escritos ao longo de mais duas décadas, mas deixava surpresos aqueles que estavam acostumados com uma métrica, uma estrutura pré-moldada de televisão que vinha da tradição, mas aos poucos estava sendo quebrada, inclusive por trabalhos já citados de Fernando Barbosa 
Lima e ganhavam uma roupagem nova em tempos de ditadura. $\mathrm{O}$ estranhamento, às vezes, era tanto que fez a jornalista Mira Zarantela chamar o quadro de Glauber de antiprograma:

[...] alvoroçando qualquer esquema que se tente estabelecer durante as gravações. Glauber Rocha faz e desfaz, grita, faz caretas, inventa, improvisa, manda que cortem a cena, dirige o movimento das câmeras e daqueles que participam com ele dos minutos em que estão no ar gravando (CRUZ apud MOTTA, 2001).

Fernando Barbosa Lima considerava Glauber o entrevistador que mais mexia com o público, "tanto que, na hora da edição, quando sente que o programa está devagar, não hesita: coloca Glauber no ar" (CAMBARÁ. 1979, p. 62). A participação de Glauber no programa foi fruto de um acordo entre ele e o produtor, determinada pelo compromisso do programa em conceder todo o material e equipe técnica, ao que Glauber poderia fazer o que quisesse, embora a produção devesse ter ampla liberdade de edição. E perceptível ao longo dos programas a preocupação de não cortar inclusive as rebarbas da filmagem. Glauber inicia, algumas vezes, dizendo: “E aí. Tá gravando?” É o antipadrão de qualidade, próprio do programa Abertura e personificado na figura de Glauber Rocha.

Para o jornalista Gabriel Priolli, o Abertura deu liberdade para as intervenções de Glauber
[...] que pulverizou a estética acrílica e falsa do padrão global. Uma câmera nervosa, inquieta e "suja", e uma atuação total- mente engajada, opinativa, "quente" a nível das reportagens e entrevistas - com esses recursos Glauber mostrou, em especial a uma geração emergente de jovens realizadores, que era possível fazer boa TV, malcomportada (PRIOLLI, 1935, p. 39).

O comentário sobre a "pulverização de estética acrílica e falsa do padrão global" torna-se mais evidente ao analisarmos o estilo visual do quadro representativo da irreverência e da negação de 
padrões estéticos estabelecidos para a televisão. Glauber sempre aparecia vestido com roupas simples, cabelo despenteado, olhar difuso, às vezes direcionado para longe da câmera, às vezes encarando a câmera como uma provocação ao telespectador, mas, na maioria das vezes, deixava a imagem de diretor sobressair. Os movimentos com as mãos, fechando o ângulo, o enquadramento, auxiliando o câmera para fazer o filme de acordo com um padrão estético híbrido, resultado da fusão entre a linguagem do cinema e a da televisão, aproveitando da experiência de produção de cinema documentário Di Glauber. O cenário variava entre o apartamento do cineasta, o bar e a rua, onde aconteciam várias entrevistas. Os figurantes faziam parte dos quadros e vinham da rua ou da família. A esposa Paula Gaitán era personagem corriqueira do programa e era comum familiares, inclusive crianças, aparecerem ao fundo em meio a uma entrevista ou fala de Glauber. Essa composição remete a visão de que o povo devia participar do programa. Esse estilo solto, descompromissado e até engraçado, influenciou futuros jornalistas, que na década de 1980, fizeram valer a irreverência de Glauber na televisão através de programas como Olhar eletrônico com Marcelo Tas que criou o personagem Ernesto Varela, repórter que com muita irreverência, pouco usual para a época, passou a desenvolver um novo tipo de jornalismo afinado com o humor, mas influenciado pelo estilo anárquico de Glauber Rocha (BENTES, 2003, p. 116).

A inovação na forma de conceber o conjunto de imagens na televisão fez com que Glauber fosse comparado, novamente, com Chacrinha e sua maestria em dominar o conjunto de câmeras do programa. Ivana Bentes, ao estudar o domínio da linguagem televisiva, definiu o comportamento dos dois artistas:

Grandes mentores das práticas artísticas com o vídeo nesse período no Brasil são figuras como Chacrinha, apresentador de programas de auditório de TV, e o cineasta Glauber Rocha. Eles exploram ao máximo o ruído da informação, a imagem conflituosa, a ruptura das regras tradicionais de se comportar diante de uma câmera de TV e a comunicação ao vivo permitida pela mídia de rede. Ambos conseguem, com suas participações libertárias na televisão brasileira, dizer 
que existe uma forma de produzir pensamento audiovisual não originado nem no cinema, nem nas regras rígidas concebidas pela própria televisão. Antes de tudo, eles chamam a atenção para o fato de que há uma nova linguagem a ser descoberta: o vídeo (MELLO, 2008, p. 95).

A composição linguística que se tem com o Abertura e com a participação de Glauber Rocha anuncia não apenas a descoberta de uma nova forma de tratar as imagens do ponto de vista técnico da televisão, mas evidencia novas possibilidades de discussão da política, muito mais amplas, pois retratam, de forma um pouco caótica, reconhecendo que esta é a intenção, opiniões antes caladas, ou, no máximo, restritas a pequenos grupos, ou, menos, à escrita. A televisão voltava a ter voz e Glauber seria um dos principais interlocutores do período.

Para Glauber, fazer o Abertura era uma atividade nova e instigante já que, segundo ele, o programa estava revolucionando a TV brasileira porque era o oposto desses "locutores caretas, de terno e gravata” (CAMBARÁ. 1979, p. 62). Tratava-se, nesse momento, de uma recusa às convenções, ao tradicionalismo e a negação de uma forma de fazer cinema e, ao mesmo tempo, de fazer televisão, já que considerava esse veículo um instrumento capaz de acabar com "mito de diretor de cinema" e ressalta o fim da profissão de cineasta, considerada atrasada, tendo pouco a contribuir com a sociedade, afirmando que o moderno está na "literatura e no tape de televisão" (CAMBARÁ. 1979, p. 62). Esta afirmação remete a fala de Glauber desde o final da década de 1960, quando já defendia a televisão contra o preconceito firmado entre as pessoas de cinema.

A grande constatação feita por Glauber em relação ao programa Abertura está no fato de que este seria o prenúncio de uma nova televisão marcada pelo jornalismo. $\mathrm{O}$ futuro da TV estaria nele e seria assim que aconteceria o desenvolvimento cultural da televisão. A atividade jornalística, levando informação e cultura, ganharia os espaços televisivos, acabando com outros produtos culturais produzidos pela televisão. Profetizava o fim das telenovelas: "A novela já era, como todos esses autores e atores que fazem esse tipo de trabalho” (CAMBARÁ. 1979, p. 62). A crítica foi endereçada 
àqueles a quem o cineasta disse conhecer, em 1968, como membros da esquerda e que em 1979, trabalhando na televisão, se tornaram de direita, mas mantendo um discurso pretensamente de esquerda, o que configura uma contradição que levaria à descrença na ação desses profissionais. $\mathrm{O}$ sucesso dessa televisão não seria possível com pessoas assim. A crítica pretende, supostamente, indagar sobre a legitimidade de um discurso evasivo e sem reconhecimento da sociedade, o estranhamento social poderia levar ao fracasso das narrativas. A genialidade de Glauber não foi o suficiente para garantir uma leitura e um prognóstico eficaz sobre o futuro da televisão e das telenovelas no Brasil.

\section{Considerações finais}

A participação de Glauber Rocha no programa Abertura revela o esforço de fazer na televisão aquilo que o cineasta já fazia no cinema, ou seja, provocar. Essa provocação era comum aos ideais da estética da fome do Cinema Novo e acompanhou o cineasta em suas experiências com o cinema até chegar a televisão. $\mathrm{O}$ sucesso dessa investida deu-se pelo reconhecimento da linguagem televisiva acoplada à linguagem cinematográfica.

Ao longo de anos, a experiência adquirida fora do Brasil possibilitou a Glauber explorar novos recursos cênicos na construção da ideia de apresentador. Claro e Câncer, assim como Di, são exemplos de exercícios que geraram um aprendizado que foi levado para telinha.

A participação na televisão deu mais visibilidade a Glauber Rocha e possibilitou uma intervenção social mais imediata, fazendo com que seu discurso crítico de esquerda ou de direita provocasse reações e reflexões, mas deixando claro seu posicionamento de inovação, de ruptura com uma forma de fazer televisão que se distanciava do grande público. 


\section{GLAUBER ROCHA IN TELEVISION WAY}

Abstract: This article aims to analyze the intellectual trajectory of Glauber Rocha, from his political and cultural experiences over the years 1970 to become a TV presenter. In his film production done abroad it is possible to realize an approach to television language, a kind of preparation for activity that would develop. Besides the films, intellectual production expressed in books, newspapers and magazines was the reason for analysis. In 1979, the Bahian filmmaker had an experience in program Abertura aired by Tupi Network. Despite being only 9 months in the air, his participation was intense, setting one of the most significant moments of Brazilian television in the 70s.

Keywords: TV. Opening. Glauber. Cinema.

\section{Notas}

${ }^{1}$ Devemos lembrar da força do pensamento de Theodore Adorno entre os artistas e intelectuais do período. Em 1954 foi lançado o artigo Television and mass culture Patterns no qual, a partir de amostragens de alguns programas, Adorno condena a televisão por sua linguagem mercadológica e pelo seu caráter ideológico, pois afirma que ao invés de estimular um pensamento autônomo, o veículo incute uma falsa consciência e promove um ocultamento da realidade.

${ }^{2}$ Chacrinha foi o personagem criado por Abelardo Barbosa de Medeiros responsável por um programa de auditório de grande popularidade que esteve no ar desde a década de 1960 até 1980. Ficou famoso pelas frases Alô, alô, Teresinha! e Quem quer Bacalhau? Apresentava o programa sempre fantasiado e num estilo descontraído e irreverente, jogando frutas e até pedaços de bacalhau para o público.

\section{Referências}

ADORNO, Theodor. Television and the patterns of mass culture. Quaterly of Film, Radio and Television, v. 8, 1954.

ARAÚJO, Luciana Corrêa de. Glauber Rocha, Claro, Itália, 1975. Contracampo: Revista de Cinema, [s.l.], [s.d.]. Disponível em: <http://contracampo.com.br/74/ claro.htm> Acesso em: 17 nov. 2012. 
BENTES, Ivana. Cartas ao mundo. São Paulo: Companhia das Letras, 1997. p. 411. . Vídeo e Cinema: rupturas, reações e hibridismo in Made in Brasil. Três décadas do vídeo brasileiro. Organização Arlindo Machado. São Paulo: Itaú Cultural, 2003.

CAMBARÁ, Isa. Glauber Rocha, agora é estrela de TV. Folha de São Paulo, São Paulo, 13 maio 1979, p. 62.

CARDOSO, Maurício. Glauber Rocha e a tentação do exílio (1972-1976). In: SANTOS, Idelette Muzart-Fonseca dos; ROLLAND, Denis (Dir.). L'exil brésilien en France. Histoire et imaginaire. Paris: L'Harmattan, 2008, p. 327-339. Disponível em: 〈http://diversitas.fflch.usp.br/node/1435>. Acesso em: 7 out. 2012.

CARDOSO, Maurício. O Cinema Tricontinental de Glauber Rocha: política, estética e revolução (1969-1974). Tese (Doutorado em História)-Departamento de História, Universidade de São Paulo, São Paulo, 2007.

NETO, Araújo. A revisão histórica de Glauber. Jornal do Brasil, Rio de Janeiro, 16 jan. 1973.

LIMA, Érico Oliveira de Araújo; FURTADO, Sylvia Beatriz Bezerra. Do moderno e do contemporâneo: políticas da imagem em Câncer, de Glauber Rocha. In: CONGRESSO DE CIÊNCIAS DA COMUNICAÇÃO NA REGIÃO NORDESTE, 13., 2011, Maceió. Anais... Maceió: Sociedade Brasileira de Estudos Interdisciplinares da Comunicação, 2011.

LUKACS, George. Arte e Sociedade. Escritos estéticos (1932-1967). Rio de Janeiro: Editora da UFRJ, 2009.

MATTOS, Tetê. A imaginação cinematográfica em Di-Glauber. In: TEXEIRA, Francisco Elinaldo (Org.). Documentário no Brasil: tradição e transformação. São Paulo: Summus Editorial, 2004.

MELLO, Christine. Extremidades do vídeo. São Paulo: Editora SENAC, 2008.

MOTA, Regina. A épica eletrônica de Glauber: um estudo sobre cinema e TV. Belo Horizonte: Editora UFMG, 2001.

NETTO, Araújo. A Revisão Histórica de Glauber. Jornal do Brasil, Rio de Janeiro, 16 jan. 1973.

PRIOLLI, Gabriel. A tela pequena no Brasil grande. In: BARBOSA LIMA, Fernando; MACHADO, Arlindo; PRIOLLI, Gabriel. Televisão e Vídeo. Rio de Janeiro: Zahar, 1985.

ROCHA, Glauber. Entrevista concedida a Cícero Sandroni. Jornal do Brasil, Rio de Janeiro, 8 jun. 1979. 
. Manifesto Eztetyka da fome. Comunicação apresentada na Retrospectiva do cinema Latino-americano organizado pelo Instituto Columbianum em Gênova em 1965. Disponível em: 〈http://tempoglauber.com.br/t_estetica.html〉. Acesso em: 14 out. 2012.

. Entrevista: Glauber Rocha. Revista ALCEU, Rio de Janeiro, v. 7, n. 13, p. 5-21, jul./dez. 2006.

. Revisão crítica do cinema brasileiro. São Paulo: Cosac Naify, 2003. . A Revolução do Cinema Novo. São Paulo: Cosac Naify, 2004.

ROCHA, Luís Alberto. Câncer, de Glauber Rocha. Disponível em: <http:// contracampo.com.br/30/cancer.htm>. Acesso em: 27 dez. 2012.

VILLAÇA, Mariana Martins. Cinema cubano: revolução e política cultural. São Paulo: Alameda, 2010.

VIZEU, Carlos Alberto. Depoimento concedido a Paulo Roberto de Azevedo Maia. Rio de Janeiro, 19 mar. 2011.

Recebido em: 25/03/2018

Aprovado em: 30/08/2018 
